\title{
Pengembangan Program Studi Perbankan Syariah Berbasis Integrasi Peran Bank Syariah Bagi Sektor Riil UMKM
}

\author{
Sudirman, ${ }^{1)}$ Trimulato $^{2 *}$, Kamaruddin ${ }^{3)}$, Iryani $^{4)}$ \\ ${ }^{1234}$ Fakultas Ekonomi dan Bisnis Islam Universitas Islam Negeri Alauddin Makassar \\ *Email korespondensi: tri.mulato@uin-alauddin.ac.id
}

Sharia banking are interested in getting involved channeling financing to the real sector of SMEs, including Bank BNI Syariah Makassar and Bank Panin Dubai Syariah Makassar. The purpose of this study is to determine the development of SMEs financing provided by sharia banking. Then to find out the role of sharia banking for the distribution financing for SMEs in the city of Makassar. As well as to find out the form of integration of the development of the department of sharia banking UIN Alauddin Makassar, through the distribution of financing for SMEs in sharia banking institution. This type of research is a field research, by taking data directly. The nature of the research is qualitative. The data source uses primary data and secondary data related to the research theme. The data analysis technique used in this research is qualitative descriptive, which describes the objects in the study. The results of this study indicate the development of the distribution of financing in sharia banking reaching 15.93 percent. Then Bank BNI Syariah and Bank Panin Dubai Syariah Makassar channeled financing to SMEs sector, reaching 20 percent. The form of integration in the development of departement sharia banking is by presenting courses on object management of financing sharia banking and courses on SMEs business.

Keywords: Sharia Banking, Financing of SMEs, and Departement of Sharia Banking UIN Alauddin Makassar

\begin{abstract}
Abstrak
Bank syariah tertarik untuk melibatkan diri dalam menyalurkan pembiayaan pada sektor riil UMKM, termasuk Bank BNI Syariah Makassar dan Bank Panin Dubai Syariah Makassar. Tujuan penelitian ini untuk mengetahui perkembangan pembiayaan UMKM yang diberikan oleh bank syariah. Kemudian untuk untuk mengetahui peran perbankan syariah untuk penyaluran pembiayaan UMKM di kota Makassar. Serta untuk mengetahui bentuk integrasi pengembangan program studi Perbankan Syariah UIN Alauddin Makassar, melalui penyaluran pembiayaan UMKM di Bank Syariah. Jenis penelitian yang digunakan adalah studi lapangan, dengan melakukan pengambilan data secara langsung. Sifat penelitian yaitu kualitatif. Adapun sumber data menggunakan data primer dan data sekunder yang berhubungan dengan tema penelitian. Teknik analisis data yang digunakan dalam penelitian ini adalah deskriptif kualitati, yang menguraikan objek dalam penelitian. Hasil penelitian ini menunjukkan adanya perkembangan penyaluran pembiayaan di bank syariah mencapai 15,93 persen. Kemudian Bank BNI Syariah dan Bank Panin Dubai Syariah Makassar menyalurkan pembiayaan pada sektor UMKM, mencapai 20 persen. Bentuk integrasi dalam pengembangan program studi perbankan syariah yaitu dengan menghadirkan mata kuliah manajemen pembiayaan perbankan syariah dan mata kuliah tentang usaha UMKM.
\end{abstract}

Kata Kunci: Bank Syariah, Pembiayaan UMKM, dan Program Studi Perbankan Syariah UIN Alauddin Makassar

Saran sitasi: Sudirman., Trimulato., Kamaruddin., \& Iryani. (2021). Pengembangan Program Studi Perbankan Syariah Berbasis Integrasi Peran Bank Syariah Bagi Sektor Riil UMKM. Jurnal Ilmiah Ekonomi Islam, 7(02), 621-637. doi: http://dx.doi.org/10.29040/jiei.v7i2.2474

DOI: http://dx.doi.org/10.29040/jiei.v7i2.2474

\section{PENDAHULUAN}

Eksistensi lembaga keuangan bank menjembantani pertemuan antara pihak yang memerlukan dana untuk modal kerja dan investasi dengan pihak yang memiliki kelebihan dana.
Tersedianya sumber dana untuk berusaha yang didukung oleh kemudahan mediasi perbankan yang mendorong ekspansi usaha seta menghilangkan dana mengaggur. Bank syariah adalah bank yang mekanisme kerjanya menggunakan sistem bagi hasil, 


\section{Jurnal Ilmiah Ekonomi Islam, 7(02), 2021, 622}

tidak menggunakan mekanisme bunga. Bank Islam adalah lembaga keuangan perbankan yang operasionalnya dan produknya dikembangkan berdasarkan Al-qur'an dan Sunnah Nabi SAW. (Gita. 2006)

Ide dasar sistem perbankan Islam sebenarnya dapat dikemukakan dengan sederhana. Operasi institusi keuangan Islam terutama berdasarkan pada prinsip PLS (porfit and loss sharing bagi untung dan rugi). Prinsip bagi hasil ini dalam keuangan Islam sangat dianjurkan dan merupakan solusi yang pantas dan relefan untuk mengatasi masalah alokasi dana yang terbatas, baik yang berupa dana pinjaman atau tabungan dengan maksud supaya pengelolaan dan pembiayaan bisnis secara efektif dapat tercapai. Bank Islam tidak membebankan bunga, melainkan mengajak partisipasi dalam bidang usaha yang didanai. Para deposan juga sama-sama mendapat bagian dari keuntungan bank sesuai dengan rasio yang telah ditetapkan sebelumnya. Dengan demikian ada kemitraan antara bank Islam dan para deposan di satu pihak, dan antara bank para nasabah investasi sebagai pengelola sumber daya para deposan dalam berbagai usaha produktif dipihak lain.(Algaoud dan Mervyn K, 2001)

Di Indonesia, selain melalui lembaga perbankan syariah, sistem ekonomi syariah juga diimplemtasikan, melalui berbagai lembaga keuangan mikro syariah atau lebih dikenal dengan BMT (Baitu Mal wattamwil). Kehadiran BMT bertujuan untuk meningkatkan kualitas usaha ekonomi untuk kesjahteraan anggota pada khususnya dan masyarakat pada umumnya. Dalam oprasionalnya BMT sangat dekat dan bersentuhan langsung dengan perekonomian masyarakat. Kegiatan yang dilakukan seperti kegiatan BMT dengan sektor riil yang meminimalkan kegiatan spekulasi dan memaksimalkan kemapuan masyarakat dalam bidang produksi dengan pembiayaan-pembiayaan yang dijalankan dengan prinsip kebersamaan dan persaudaraan. Administrasi dan mekanisme kerja BMT sama dengan BPR Syariah dengan ruang lingkupdan produk yang dihasilkan berbeda.(Mursal, 2016)

Beberapa tahun ini sejumlah bank berkonsep ekonomi Islam ini memiliki program memberi pembiayaan terhadap UMKM. Tujuannya agar para pelaku UMKM bisa semakin berkembang dan terus berkontribusi bagi percepatan pembangunan nasional. Salah satu produk perbankan syariah yang menyentuh para pelaku UMKM adalah kredit usaha rakyat (KUR). Hampir semua bank konvensional yang memiliki produk syariah bergerak di produk ini, seperti beberapa di antaranya Kredit Mikro BRI Syariah, KUR Syariah Mandiri, KUR BNI Syariah, KUR Bank Jatim Syariah, dan KUR Bank Nagari Syariah. Bahkan, tahun ini KUR Syariah Mandiri menyalurkan dana sebesar Rp1,7 triliun. Angka ini naik dua kali lipat dibandingkan 2012, yang hanya Rp750 miliar. Bank-bank syariah lain juga melakukan hal ini dalam rangka membantu pelaku UMKM yang selama ini merasa kesulitan untuk mengakses permodalan ke bank-bank besar. Pasalnya, selama ini masih ada saja perbankan besar yang enggan mengeluarkan kredit untuk usaha kecil dan baru karena dinilai belum jelas prospeknya. Selain bertujuan membantu memberi akses permodalan kepada UMKM, di tubuh perbankan syariah, optimalisasi terhadap pembiayaan di sektor mikro menjadi salah satu potensi bisnis yang baik untuk masa depan. Konsultan ekonomi syariah sekaligus Managing Director at Rasyidin Consulting Wiku Suryomurti mengatakan, dalam beberapa tahun ini perbankan syariah terus gencar menyalurkan dana bagi para pelaku UMKM. Pada satu sisi pencapai target pangsa pasar 5\% memang belum tercapai (hanya 4,8\%), tapi di sektor pembiayaan UMKM kinerja bank-bank syariah mulai maksimal. Di Indonesia, ada sekitar 52 juta UMKM yang eksis hingga hari ini. Sayangnya, keberadaan mereka belum banyak terakomodasi permodalan oleh bankbank besar. Sebagian perbankan besar masih khawatir terhadap keberlanjutan UMKM tersebut. Sementara itu, kata Wiku, dalam hal ini perbankan syariah lebih mengakomodasi mereka. Pasalnya, sistem perbankan syariah lebih minimalis tingkat pengaruhnya terhadap gejolak ekonomi. (www.bankmuamalat.co.id, 2016)

PT Bank Syariah Mandiri (BSM) optimis kontribusi pembiayaan segmen usaha mikro, kecil dan menengah (UMKM) dapat terus dipertahankan. Untuk tahun ini, perseroan mematok porsinya mencapai $75 \%$ dari total pembiayaan yang ditargetkan tumbuh $25 \%$ menjadi Rp55,96 triliun. Demikian porsi UMKM diharapkan mencapai Rp42 triliun. "BSM sengaja mengejar yang ritel baik dana dan pembiayaan. Jadi kami agak puasa untuk yang korporasi, institusi yang besar-besar dananya," ujar Direktur Utama BSM Yuslam Fauzi, saat ditemui wartawan di Kantor Pusat BSM, Jakarta, belum lama ini. Perseroan mencatat per akhir 2012, kucuran pembiayaan UMKM mencapai 
Rp32,79 triliun, atau sebesar 73,3\% dari total pembiayaan sebesar Rp44,76 triliun. Pada akhir 2011, posisi pembiayaan UMKM sebesar Rp26,78 triliun, sebesar 72,9\% dari total pembiayaan Rp36,73 triliun. Pertumbuhan pembiayaan UMKM sendiri sebesar $22,45 \%$ dalam setahunan, yang juga dikontribusi pembiayaan di segmen mikro. "Kami PD (percaya diri) masuk ke mikro. Pertama IT sekarang, sehingga kami akan lebih gesit dan efisien. Kedua, Bank Mandiri juga sudah mulai kembangkan mikronya. Sebagai bank syariah, lanjutnya, BSM berusaha menjalankan nilai-nilai syariah yang salah satunya adalah dengan memberikan manfaat sebesar-besarnya bagi lingkungan dan masyarakat. Kenyataan mayoritas usaha di Tanah Air adalah usaha mikro dan kecil, lanjutnya, maka perseroan menetapkan untuk masuk ke segmen ini. (www.syariahmandiri.co.id. 2016)

Dalam hal penyaluran dana kepada masyarakat, praktinya dalam bank syariah berbeda dengan yang dilakukan pada bank konvensional. Perbedaan paling mendasar adalah tidak ada riba atau bunga dalam bank syariah, serta menggunakan sistem pembiayaan bagi hasil (musyarakah dan mudharabah). Berbeda dengan bank konvensional yang sudah disepakati sejak awal penetapan besarnya bunga dan biaya angsurannya tiap bulan, jika terdapat resiko maka semua itu hanya ditanggung oleh peminjam sehingga salah satu pihak saja yang menaggung kerugian. Perbedaan lainnya adalah hubungan bank syariah dengan nasabahnya adalah menggunakan konsep kemitraan, bahkan juga terdapat bantuan tanpa adanya jaminan karna bank syariah lebih mengedepankan kemaslahatan. Bukan bank konvensional yang hanya memperhatikan keuntungan pihak bank tanpa memikirkan nasib nasabahnya. Kemudian dalam bank syariah, kegiatan usahanya juga harus halal dan jelas objeknya agar tidak mengandung unsur spekulasi atau untunguntungan semata, hal ini lah yang menjadikan bank syariah memiliki ketangguhan dalam menghadapi krisis ekonomi. Perbankan syariah memiliki potensi yang sangat besar dalam perekonomian. Sistem perbankan syariah ini sangat cocok untuk mengembangkan UMKM yang memiliki peran strategis dalam menggerakkan pembangunan ekonomi nasional. Dengan demikian, kontribusi perbankan syariah dalam pengembangan UMKM sangat diharapkan dapat berjalan dengan lebih maksimal. Salah satu contohnya adalah dengan meningkatkan aksebilitas pembiayaannya yaitu memberikan persyaratan yang lebih mudah serta dilakukan adanya pelatihan dan pendampingan usaha. Perbankan syariah diharapkan dapat terus berkembang dalam memberdayakan usaha mikro kecil dan menengah (UMKM). (www.kompasiana.com, 2020)

Dengan memupuk budaya kewirausahaan dalam sebuah UMKM, manajer dapat menuai manfaat baik dalam memperluas perusahaan mereka lebih luas ke pasar luar negeri dan untuk membantu organisasi menjadi lebih gesit dan responsif terhadap kebutuhan pelanggan secara umum. Sejak nilai sukses pembuatan dan penangkapan sangat terkait dengan pengembangan model bisnis, ini semakin menyoroti peran orientasi wurausaha dalam sukses berwirausaha baik di dalam maupun di luar negeri. Akhirnya, untuk pembuat kebijakan, hasilnya menyoroti pentingnya pertumbuhan perusahaan yaitu, UMKM yang bersedia mengambil risiko finansial dan memerlukan strategis untuk ekspansi internasional. (Asemokha et al., 2019)

Meningkatnya animo masyarakat terhadap bank syariah khususnya dalam penyaluran dana bagi Usaha Mikro Kecil dan Menengah (UMKM), menunjukan betapa pentingnya kehadiran bank syariah. Selain itu trend yang mulai berfikir untuk menerapkan pola hidup yang sesuai dengan syariah Islam, begitu juga dalam hal perekonomian. Sehingga ketika bank syariah mulai berkembang dan masyarakat dapat mengakses dengan mudah berbagai produk atau fasilitasnya, maka dengan kesadaran sendiri mulai memindahkan transaksi dana kususnya meminjam ke bank syariah. Bank syariah sebagai lembaga perantara antara pihak yang kelebihan uang (pemodal/penabung) dan pihak yang kekurangan modal. Praktek pembiayaan syariah diarahkan menuju pembiayaan dengan prinsip bagi hasil yang menekankan pola hubungan kemitraan antara pihak bank dan nasabah. Prinsip bagi hasil dapat dilakukan dalam empat akad, yaitu mudharabah, musyarakah, muzara'ah, dan musaqah. Namun dalam praktiknya akad yang banyak dipakai adalah mudharabah dan musyarakah. (Zamroni. 2013) 
Jurnal Ilmiah Ekonomi Islam, 7(02), 2021, 624

Tabel 1.1. Porsi Penyaluran Pembiayaan Bank Syariah Oktober 2019

\begin{tabular}{|c|c|c|c|c|c|c|}
\hline \multirow[t]{2}{*}{ No } & \multirow{2}{*}{$\begin{array}{c}\text { Jenis } \\
\text { Pembiayaan }\end{array}$} & \multicolumn{3}{|c|}{ Jenis Bank Syariah } & \multirow{2}{*}{$\begin{array}{c}\text { Jumlah } \\
\text { Pembiayaan }\end{array}$} & \multirow{2}{*}{$\begin{array}{c}\text { Porsi } \\
\text { Pembiayaan }\end{array}$} \\
\hline & & $\begin{array}{l}\text { Bank Umum } \\
\text { Syariah }\end{array}$ & $\begin{array}{l}\text { Unit Usaha } \\
\text { Syariah }\end{array}$ & $\begin{array}{c}\text { Bank Pembiayaan } \\
\text { Syariah }\end{array}$ & & \\
\hline 1 & Konsumsif & $89.638,000$ & $64.111,000$ & $4.780,773$ & $158.529,773$ & $44,60 \%$ \\
\hline 2 & Investasi & $50.718,000$ & $32.552,000$ & $1.553,855$ & $84.823,863$ & $23,86 \%$ \\
\hline \multirow[t]{2}{*}{3} & Modal Kerja & $78.341,000$ & $29.924,000$ & $3.887,552$ & $112.152,55$ & $31,54 \%$ \\
\hline & TOTAL & 218.697,00 & $126.587,00$ & $10.222,18$ & $355.506,18$ & 100 \\
\hline
\end{tabular}

Sumber : Statistik Perbankan Syariah Oktober 2019. Otoritas Jasa Keuangan (Data diolah) [8]

Data diatas menunjukkan adanya penyaluran pembiayaan yang disalurkan dari tiga jenis Bank Syariah yang ada di Indonesia yaitu Bank Umum Syariah (BUS), Unit Usaha Syariah (UUS), dan Bank Pembiayaan Syariah (BPRS). Pembiayaan terbesar disalurkan oleh BUS, kemudian UUS, dan terkecil UUS. Dari jenis penyaluran pembiayaan terbanyak disalurkan pada produk Konsumtif sebesar 44,60 persen atau sebesar 158.529.773.000.000. Sedangkan terkecil disalurkan pada produk investasi sebesar 23,86 persen atau 112.152.550.000.000. Perlu dukungan dan dorongan agar bank syariah dapat meningkatkan pembiayaan produktifnya bukan konsumtifnya agar lebih berkontribusi dalam perkembangan ekonomi.

Peran perbankan syariah dalam pengembangan UMKM sangat diperlukan, mengingat segmen ekonomi UMKM merupakan segmen ekonomi yang banyak di negeri ini. Kemudian UMKM memiliki kekuatan ekonomi yang kuat, terbukti ketika terjadi krisis di tahun 1998, segmen ekonomi UMKM dapat bertahan dan tidak terkena dampak. Selain itu segmen ekonomi UMKM banyak menyerap tenaga kerja, termasuk di daerah-daerah sehingg menjadi pendapatan dari masyarakat tertentu. Maka dari itu banyak lembaga yang tertarik untuk mengembangkan UMKM, dengan pemberian modal, termasuk dari pihak perbankan syariah. Bahkan beberapa bank syariah memberikan layanan porsi khusus untuk pemberian layanan pembiayaan untuk usaha UMKM. Selain bertugas untuk membantu dari sisi permodalan, bank syariah sebagai mitra dari UMKM dapat berperan dalam proses pengembangan usaha nasabah atau mitra, melalui pengawasan yang maksimal, sentuhan saran-saran dalam pengembangan usaha.

Program studi perbankan syariah fakultas ekonomi dan bisnis Islam UIN Alauddin Makassar merupakan program studi yang konsen dan reson terhadap perkembangan perbankan syariah. Program studi ini mulai beroperasi pembelajaran pada tahun
2016. Prodi ini menerima banyak mahasiswa setiap tahunnya dan telah memperoleh akreditasi. Meskipun tergolong baru program studi ini telah melakukan banyak kegiatan yang melibatkan langsung dengan banyak intansi lembaga keuangan syariah yang berada di kota makassar. Dalam rangka lebih mengembangkan program studi perbankan syariah ini diperlukan lebih banyak kegiatan dan terobosan sebagai respon atas perkembangan keuangan syariah baik secara nasional dan internasional. Salah satu upaya meningkatkan pengembangan progran studi perbankan syariah, maka perlu dilakukan integrasi pembelajaran terkait peran perbankan syariah terhadap kontribusinya terhadap usaha sektor riil UMKM khususnya di Kota Makassar. Tujuannya agar jurusan perbankan syariah dapat lebih mengenal bentuk dari usaha UMKM yang ada, serta besar kontribusi bank syariah dalam menyalurkan pembiayaan untuk UMKM. Dengan adanya integrasi ini akan meningkatkan dua poin pengembangan program studi perbankan syariah, yang dapat berkonsen pada usaha sektor rill UMKM dan perbankan syariah. Serta hal-hal yang terkait dengan strategi bank syariah dalam merangkul UMKM. Pembiayaan bank syariah untuk UMKM menjadi objek yang penting dalam pengajaran dalam perkuliahan pada jurusan perbankan syariah. Kedua sektor ini, bank syariah dan UMKM untuk saat ini tidak dapat dipisahkan, satu sama lain. Lembaga perbankan syariah sebagai lembaga intermediari dan kemudian UMKM menjadi sektor riil yang banyak membutuhkan modal atau pembiayaan, yang dapat dipenuhi oleh bank syariah. Hampir semua bank syariah memberikan porsi khusus untuk segmen ekonomi UMKM.

Dari uraian diatas peneliti merasa tertarik untuk melakukan penelitian lebih lanjut terkait peran pembiayaan perbankan syariah dalam pembiayaan UMKM, dan kemudian integrasi dengan pembelajaran yang dilakukan pada program studi perbankan syariah 


\section{Jurnal Ilmiah Ekonomi Islam, 7(02), 2021, 625}

Fakultas Ekonomi dan Bisnis Islam Universitas Islam Negeri Alauddin Makassar. Tujuan dari penelitian ini untuk mengetahui perkembangan pembiayaan bank syariah pada sektor UMKM. Kemudian untuk mengetahui peran pembiayaan perbankan syariah terhadap sektor UMKM di Kota Makassar. Serta ntuk mengetahui integrasi peran pembiayaan perbankan syariah untuk sektor UMKM dengan pengembangan program studi perbankan syariah Universitas Islam Negeri Alauddin Makassar.

\section{TINJAUAN PUSTAKA}

Pembiayaan berdasarkan prinsip syariah adalah penyediaan uang atau tagihan yang dipersamakan dengan itu berdasarkan persetujuan atau kesepakatan antara bank dengan pihak lain yang mewajibkan pihak yang dibiayai untuk megembalikan uang atau tagihan tersebut setelah jangka waktu tertentu dengan imbalan atau bagi hasil. Prinsip syariah adalah aturan perjanjian berdasarkan hukum islam antara bank dan pihak lain untuk penyimpanan dana dan atau pembiayaan kegiatan usaha, atau kegiatan lainnya yang dinyatakan sesuai dengan syariah, antara lain pembiayaan berdasarkan prinsip hasil (mudharabah), pembiayaan berdasarkan prinsip penyertaan modal (musyarakah), prinsip jual beli barang dengan memperoleh keuntungan (murabahah), atau pembiayaan barang modal berdasarkan prinsip sewa murni tanpa pilihan (ijarah), atau dengan adanya pilihan pemindahan kepemilikan atas barang yang disewa dari pihak bank oleh pihak lain (ijarah wa iqtina). (Aisyah. 2014)

Kontrak pembiayaan (financing contract) menawarkan jalan untuk menciptakan dan memperluas pembiayaan, memfasilitasi pembiayaan kontrak transaksional, dan memberikan saluran untuk pembentukan kapital dan mobilisasi sumber daya antara investor dan pengusaha. Ciri utama kontrak pembiayaan adalah tidak adanya kontrak utang. Kontrak pembiayaan dimaksudkan untuk pendanaan kontrak transaksional dalam bentuk trade finance (pembiayaan perdagangan) atau asset-backed securities (sekuritas berbasis trade finance (sekuritas berbasis aset), atau menyediakan modal melalui equity partnership (kemitraan dalam modal) yang dapat diwujudkan dalam beberapa bentuk seperti kemitraan, penyertaan kepemilikan atau kemitraan lainnya.(Muhamad. 2014)

Pembiayaan merupakan salah satu tugas pokok bank, yaitu pemberian fasilitas penyediaan dana untuk memenuhi kebutuhan pihak-pihak yang merupakan defisit unit. Menurut sifat penggunaannya, pembiayaan dapat dibagi menjadi: (Kholis. 2008)

a. Pembiayaan konsumtif, yaitu pembiayaan yang digunakan untuk memenuhi kebutuhan konsumsi, yang akan habis digunakan untuk dipakai memenuhi kebutuhan.

b. Pembiayaan produktif, yaitu pembiayaan yang ditujukan untuk memenuhi kebutuhan produksi dalam arti luas, yaitu untuk peningkatan usaha, baik usaha produksi, perdagangan, maupun investasi.

Menurut keperluannya, pembiayaan produktif dapat dibagi menjadi;

a. Pembiayaan modal kerja, yaitu pembiayaan untuk memenuhi kebutuhan (1) peningkatan produksi, baik secara kuantitatif, yaitu jumlah hasil produksi, maupun secara kualitatif, yaitu peningkatan kualitas atau mutu hasil produksi; dan (2) untuk keperluan perdagangan atau peningkatan utility of place dari suatu barang.

b. Pembiayaan investasi, yaitu untuk memenuhi kebutuhan barang-barang modal (capital goods) serta fasilitas-fasilitas yang erat kaitannya dengan itu.

Bank syariah tidak pernah meminjamkan uang tetapi menjual barang kepada nasabah dengan memberikan fasilitas untuk mencicil harga barang. Bank syariah menyewakan barang kepada nasabah untuk jangka waktu tertentu. Untuk memperoleh barang yang dijual atau disewakan kepada nasabah itu, bank syariah membeli dari pemasok barang. Tegasnya, nasabah tidak pernah memperoleh dana berupa pinjaman dari bank syariah. Modus operandi bank syariah yang demikian itu adalah karena bank syariah tidak boleh membebankan bunga kepada nasabah. Artinya, karena berlakunya larangan memberikan pinjaman uang dengan bunga, maka bank syariah tidak memberikan fasilitas pemberiaan dana dengan langsung kepada nasabah seperti halnya bank konvensional, tetapi melalui modus operandi lain. (Remy, 2014)

Sri Maryati dalam tulisannya yang berjudul Peran Bank Pembiayaan Syariah Dalam Pengembangan UMKM dan Agrisbisnis Pedesaan di Sumatra Barat dalam jurnal Economica menyimpulkan bahwa Berdasarkan karakteristik usaha, pada umumnya nasabah pembiayaan BPRS mempunyai usaha di bidang perdagangan, usaha milik sendiri dengan tempat usaha yang juga milik sendiri dimana 
mayoritas responden dalam menjalankan usahanya tidak memiliki izin usaha resmi. Pelaku usaha juga harus berusaha mengelola usaha dengan lebih profesional dan memenuhi aspek legalitas usaha agar memudahkan bagi pihak pemerintah maupun lembaga keuangan untuk melakukan berbagai usaha pemberdayaan dan bantuan permodalan. (Maryati, 2014)

Fajar Mujaddid dan Ghaida Fathihatu Sabila dalam penelitiannya, bahwa Beban Operasional terhadap Pendapatan Operasional (BOPO) dan Non Performing Financing (NPF) berpengaruh negatif dan signifikan terhadap pertumbuhan laba (ROA) Bank Umum Syariah. Pembiayaan UMKM, CAR, BOPO, dan NPF secara bersama-sama berpengaruh terhadap pertumbuhan laba. Model regresi yang terdiri dari Pembiayaan UMKM, CAR, BOPO dan NPF sebagai variabel independen mampu menjelaskan variasi perubahan ROA sebagai variabel dependen sebesar 82.47\%. (Mujaddid dan Sabila, 2018)

Muslimin Kara dalam tulisannya menyebutkan perkembangan pembiayaan perbankan syariah dalam upaya pengembangan UMKM di Kota Makassar selama tahun 2010-2011 mengalami peningkatan yang berfluktuasi. Hal tersebut mencerminkan bahwa peran serta pembiayaan perbankan syariah dalam peningkatan usaha mikro kecil dan menengah (UMKM) di Kota Makassar belum optimal. Secara rata-rata perkembangan pembiayaan perbankan syariah selama periode Januari - Desember 2010 sebesar 14,23\%, sedangkan periode Januari September tahun 2011 sebesar 18,43\%. (Kara, 2013)

\section{METODE PENELITIAN}

Penelitian Pengembangan Program Studi ini merupakan penelitian studi lapangan (field Reserch), yang melalui proses pengambilan data melalui kunjungan ke beberapa bank syariah yang berada di kota Makassar dalam hal ini dilakukan di PT. Bank BNI Syariah cabang Makassar dan PT. Bank Panin Dubai Syariah Cabang Makassar. Kemudian terkait kontribusi dari bank syariah pada sektor riil UMKM. Dengan mengamati secara langsung bentuk penyaluran pembiayaan pada UMKM.
Penelitian ini bersifat deskriptif kualitatif yang artinya menggambarkan suatu subyek penelitian. Dalam hal ini adalah pertumbuhan produk pembiayaan produktif bank syariah di Indonesia, Kontribusi pembiayaan produktif bank syariah terhadap sektor riil UMKM dan kemudian menguraikan peran dari produk pembiayaan produktif bank syariah terhadap sektor riil UMKM.

Jenis data yang digunakan dalam tulisan ini adalah data kualitatif yang bersumber dari data primer dan data sekunder. Data primer berupa sumber data yang langsung memberikan data kepada peneliti atau data yang diperoleh langsung dari lapangan (objek penelitian), sedangkan data sekunder adalah sumber data yang tidak langsung memberikan data kepada pengumpul data (peneliti). Data-data yang digunakan penulis antara lain: Data yang diperoleh langsung melalui wawancara langsung kepada pihak bank terkait penyaluran pembiayaan pada UMKM. Teoriteori yang peneliti ambil dari berbagai literatur. Pengambilan data-data dari hasil yang telah tersaji dari suatu lembaga diantaranya Otoritas Jasa Keuangan.

Teknik pengumpulan data yang diperlukan dalam tulisan ini adalah dengan menggunakan beberapa metode yaitu: melalui wawancara langsung dengan pihak yang berhubungan langsung dengan pembiayaan di bank syariah. Kemudian melalui studi pustaka, yang dianggap relevan dengan tema penelitian. Serta melalui pengamatan terhadap pertumbuhan pembiayaan bank syariah, serta porsi pembiayaan untuk UMKM.

Metode analisis data yang digunakan adalah dengan menggunakan pendekatan kualitatif deskriptif yaitu dengan cara memaparkan perkembangan UMKM dan produk pembiayaan produktif yang dimiliki oleh bank syariah, serta perkembangan pembiayaan bank syariah bagi sektor riil UMKM. Kemudian peran lembaga keuangan Islam bagi sektor riil UMKM. Serta gambaran kontribu dari lembaga keuangan Islam bagi perkembangan sektor riil UMKM. 
Jurnal Ilmiah Ekonomi Islam, 7(02), 2021, 627

\section{HASIL DAN PEMBAHASAN}

4.1. Perkembangan Pembiayaan Bank Syariah Pada Sektor UMKM

Tabel 4.1

Pembiayaan Bank Syariah Untuk UMKM

\begin{tabular}{|c|c|c|c|c|c|}
\hline No & Jenis Bank Syariah & Jenis Pembiayaan & $\begin{array}{c}\text { Tahun } \\
2019\end{array}$ & $\begin{array}{c}\text { Bulan Maret } \\
2020\end{array}$ & Perkembangan \\
\hline 1 & $\begin{array}{c}\text { Bank Umum Syariah } \\
\text { (BUS) }\end{array}$ & $\begin{array}{l}\text { Modal Kerja } \\
\text { a. UMKM } \\
\text { b. Non UMKM } \\
\text { Investasi } \\
\text { a. UMKM } \\
\text { b. Non UMKM } \\
\text { Konsumsi } \\
\text { a. Non UMKM }\end{array}$ & $\begin{array}{l}\text { a. } 32.326 \\
\text { b. } 47.661 \\
\text { a. } 19.524 \\
\text { b. } 33.683 \\
\text { a. } 91.953\end{array}$ & $\begin{array}{l}\text { a. } 37.475 \\
\text { b. } 42.069 \\
\text { a. } 23.930 \\
\text { b. } 29.023 \\
\text { a. } 95.897\end{array}$ & $\begin{array}{l}\text { a. } 15,93 \\
\text { b. }-11,73 \\
\text { a. } 22,57 \\
\text { b. }-13,83 \\
\text { a. } 4,29\end{array}$ \\
\hline 2 & $\begin{array}{l}\text { Unit Usaha Syariah } \\
\text { (UUS) }\end{array}$ & $\begin{array}{l}\text { Modal Kerja } \\
\text { a. UMKM } \\
\text { b. Non UMKM } \\
\text { Investasi } \\
\text { a. UMKM } \\
\text { b. Non UMKM } \\
\text { Konsumsi } \\
\text { a. Non UMKM }\end{array}$ & $\begin{array}{l}\text { a. } 9.301 \\
\text { b. } 21.299 \\
\text { a. } 5.185 \\
\text { b. } 28.580 \\
\text { a. } 65.671\end{array}$ & $\begin{array}{l}\text { a. } 8.741 \\
\text { b. } 22.879 \\
\text { a. } 5.043 \\
\text { b. } 29.219 \\
\text { a. } 67.375\end{array}$ & $\begin{array}{l}\text { a. }-6,02 \\
\text { b. } 7,42 \\
\text { a. }-2,7 \\
\text { b. } 2,24 \\
\text { a. } 2,6\end{array}$ \\
\hline 3 & $\begin{array}{c}\text { Bank Pembiayaan } \\
\text { Rakyat Syariah } \\
\text { (BPRS) }\end{array}$ & $\begin{array}{l}\text { a. UMKM } \\
\text { b. Non UMKM }\end{array}$ & $\begin{array}{l}\text { a. } 5.841 .290 \\
\text { b. } 4.102 .030 \\
\end{array}$ & $\begin{array}{l}\text { a. } 6.108 .146 \\
\text { b. } 4.570 .175 \\
\end{array}$ & $\begin{array}{l}\text { a. } 4,57 \\
\text { b. } 11,41 \\
\end{array}$ \\
\hline 4 & Total & & $365.126,32$ & 372.329,32 & 1,97 \\
\hline
\end{tabular}

Dari data diatas menunjukkan adanya perkembangan pembiayaan yang disalurkan oleh perbankan syariah pada periode Desember 2019 sampai dengan Maret 2020. Ketiga jenis bank syariah yaitu Bank Umum Syariah (BUS), Unit Usaha Syariah (UUS), dan Pembiayaan Rakyat Syariah (BPRS). Ketiga jenis perbankan syariah ini menyalurkan pembiayaan pada tiga jenis pembiayaan yaitu Modal Usaha, Investasi, dan Konsumsi. Kemudian segmen pembiayaan pada sektor UMKM dan Non UMKM. Dari data diatas menunjukkan bahwa BUS mengalami pertumbuhan penyaluran pembiayaan terbesar pada sektor UMKM yaitu dengan pertumbuhan mencapai 15,93 persen pada modal kerja, dan pertumbuhan terbesar mencapai 22,57 persen pada jenis pembiayaan Investasi.

Beberapa pembiayaan mengalami penurunan seperti pada UUS. Pada pembiayaan Modal Kerja UMKM mengalami penurunan sebesar $-6,02$ persen,dan pada pembiayaan Investasi juga turun sebesar $-2,7$ persen. Jika dilihat secara keseluruhan maka penyaluran pembiayaan bank syariah mengalami pertumbuhan 1,97 persen. Perlu upaya untuk mendorong perkembangan pembiayaan bank syariah khususnya untuk UMKM agar tumbuh lebih lagi. Apalagi jika dilihat secara nominal penyaluran pembiayaan masih didominasi pada pembiayaan konsumtif yang artinya bukan untuk UMKM.

Literasi keuangan, akses ke keuangan dan sikap risiko keuangan secara langsung mempengaruhi keberlanjutan UMKM, sementara akses ke keuangan dan sikap risiko keuangan secara parsial memediasi hubungan antara literasi keuangan dan keberlanjutan. Dengan demikian literasi keuangan merupakan prediktor penting dari akses ke keuangan, sikap risiko keuangan dan keberlanjutan di UMKM. Selanjutnya pengaruh langsung dari sikap risiko keuangan terhadap keberlanjutan UMKM adalah lebih besar dari literasi keuangan dan akses keuangan. Hal ini menunjukkan bahwa sikap manajer merupakan faktor penting dalam keberlangsungan UMKM, karena secara langsung mempengaruhi organisasi pengambilan keputusan. Selain perluasan literatur pengembangan UKM dengan menunjukkan bahwa akses ke keuangan dan sikap risiko keuangan merupakan anteseden keberlanjutan UKM dan menyarankan cara baru untuk meningkatkan keberlanjutan UMKM, khususnya di negara berkembang. (Ye \& Kulathunga, 2019) 


\section{Jurnal Ilmiah Ekonomi Islam, 7(02), 2021, 628}

\subsection{Penyaluran Pembiayaan untuk UMKM di PT. Bank BNI Syariah Cabang Makassar}

Telah dilakukan wawancara dengan bapak Andika sebagai divisi bagian penyaluran pembiayaan UMKM di Bank BNI Syariah Makassar yang berkantor di Jalan Sam Ratulangi Makassar. Adapun hasil dari wawancara sebagai berikut;

Dalam penyaluran pembiayaan untuk usaha UMKM Bank BNI Syariah Makassar memberikan porsi yang cukup besar mencapai $20 \%$ dari total pembiayaan yang disalurkannya. Angka $20 \%$ terbilang cukup besar, bagi porsi pembiayaan, mengingat bank BNI Syariah merupakan salah bank syariah yang besar, yang mana segmen dan fasilitas yang dimilikinya cukup lengkap bagi para nasabahnya. Kemudian Bank BNI Syariah juga memberikan pembiayaan pada proyek-proyek besar, dengan nominal pembiayaan besar, dalam kondisi demikian BNI Syariah juga tetap memberikan porsi pembiayaan bagi pelaku usaha UMKM. Bahkan memiliki target agar penyaluran dananya sebanyak 20 \% dapat tersalurkan untuk usaha produktif UMKM. Dukungan bank BNI Syariah untuk mengembangkan ekonomi UMKM di kota makssar, sebagai respon bahwa di kota Makassar pelaku bisnis semakin banyak dan berkembang, sehingga dapat berkontribusi dalam menyalurkan pembiayaan. Sektor mikro UMKM dapat mengajukan pembiayaan kepada Bank BNI Syariah dengan nominal terendah sampai dengan nominal tertentu yang dikhususkan untuk UMKM dengan syarat dan ketentuan yang berlaku. Penyeluran pembiayaan di Bank BNI Syariah Makassar banyak disalurkan untuk keperluan dengan pembiayaan KPR, dan pembiayaan yang paling minim disalurkan oleh BNI Syariah Makassar adalah pembiayaan Otomotif. Dengan demikian porsi pembiayaan yang disalurkan Bank BNI Syariah untuk usaha UMKM merupakan salah satu segmen yang menjadi perhatian dari pihak bank BNI Syariah, walaupun belum menjadi prioritas. Kedepannya segmen ini akan terus ditingkatkan, dengan melihat potensi dan peluang yang dimiliki oleh para pelaku usaha UMKM, BNI Syariah akan lebih memberikan fokus dan meningkatkan layanan untuk pemberian pembiayaan untuk UMKM.

Perkembangan pembiayaan untuk UMKM di Bank BNI Syariah bisa dibilang cukuap baik, dengan makin banyaknya nasabah pelaku UMKM ingin mengembangkan usahanya sehingga mengajukan pembiayaan di Bank BNi Syariah cabang Makassar untuk penambahan modal usaha. Selanjutnya BNI
Syariah akan memproses pengajuan pembiayaan tersebut, dan melakukan analisis kepada calon nasabah pembiayaan produktif UMKM. Sehingga akan diukur sejauh mana kemampuan nasabah atas pembiayaan yang diajukannya. Jadi dilihat dan pelajari atas setiap pembiayaan yang diajukan, apakah layak dibiayai atau belum, atau mungkin nominal pembiayaan yang terlalu besar sehingga diminta untuk diturnkan nominalnya, kemudian didalami usahausaha yang dimiliki nasabah. Jangan sampai nominal pembiayaan yang diajukan itu terlalu besar sehingga apabila disetujui, akan menyulitkan dari nasabah sendiri. Analisis pembiayaan untuk usaha UMKM sama dengan pengajuan pembiayaan lainnya, sama dengan berlaku di banyak bank lainnya. Jadi dipastikan kemampuan para nasabah jangan sampai memberatkan atau jangan sampai usahanya malah tidak terbantukan. Jadi benar-benar diharapkan setiap nasabah yang dibiayai bank BNI Syariah Makassar bisa berkembang usahanya. Sehingga BNI Syariah Makassar dapat optimal dalam menyalurkan pembiayaan, bank BNI Syariah juga akan memberikan modal yang lebih besar kepada pelaku UMKM yang sebelumnya telah lancar sebelumnya, jika ingin menambah pembiayaannya dipersilahkan. Kembali lagi tetap harus disesuaikan dengan kemampuannya untuk memenuhi kewajibannya kepada bank. Gambarannya misalnya sebelumnya nasabah memiliki pembiayaan 20.000.000 juta dan ternyata lancar dan memiliki track record yang baik maka pihak bank akan mempertimbangkan jika si nasabah UMKM ingin meningkatkan atau menambah nominal pembiayaannya. Jadi perkembangan pembiayaan UMKM di Bank BNI Syariah bisa dibilang cukup baik, dengan makin banyakknya nasabah yang tertarik dan mengajukan aplikasi pembiayaan untuk usaha UMKM, dari waktu ke waktu.

Dalam menyalurkan pembiayaan UMKM di Bank BNI Syariah, untuk memastikan dan mengusahakan agar setiap pembiayaan yang disalurkan itu lancar dan pelaku usaha juga merasakan manfaat maka BNI Syariah Makassar memberikan kriteria atau ketentuan-ketentuan pelaku usaha yang dianggap layak diberikan pembiayaan untuk UMKM. Jadi tidak semua nasabah yang mengajukan pembiayaan baik pelaku UMKM atau pembiayaan lainnya akan disetujui keseluruhan, tetapi harus dilakukan analisis dan dipelajari. Setelah nasabah mengajukan pembiayaan dicek dokumen dan 
informasi yang diberikan lalu dipelajari secara baik, sama seperti biasa dalam analisis pembiayaan di terapkan prinsip $5 \mathrm{C}+1 \mathrm{~S}$, untuk pembiayaan yang harus dipenuhi jika mengajukan pembiayaan di bank Syariah. 5C + 1S yang terdiri dari character (Karakter), Capital (Modal), Capasity (Kemampuan), Condition (Kondisi), Colleteral (Jaminan), dan Syariah. Aspek Charakter harus dipenuhi oleh nasabah pembiayaan, yaitu harus memiliki karakter yang baik dan layak untuk dipenuhi. Karena ini dapat menjadi pertimbangan bagi pihak bank, ini dapat dilihat dari track record nasabah pembiayaan jika pernah memiliki kredit atau pembiayaan di bank lain sebelumnya. Atau biasa melalui BI Cheking, melihat bagaimana rekam jejak dari calon nasabah pembiayaan. Pihak bank juga dapat terjun langsung kelapangan dengan meilihat kondisi si nasabah dengan bertanya atau menemui tetangga atau lingkungan tempat tinggalnya, untuk menjadi bahan pertimbangan. Segala informasi terkait dengan nasabah yang mengajukan pembiayaan akan menjadi bahan pertimbangan bagi bank syariah dalam memutuskan pencairan pembiayaan. Karakter termasuk hal yang penting bagi bank syariah, sejauh mana karakter dari nasabah sehingga untuk keberlanjutan pembiayaan dapat berjalan lancar. Kedua dari aspek capital atau modal yang dimiliki oleh nasabah yang mengajukan pembiayaan, harus dipastikan berapa capital yang dimilikinya sehingga menjadi pertimbangan bagi bank BNI Syariah cabang Makassar untuk memberikan besaran nilai pembiayaan kepada nasabah. Jangan sampai nilai pinjamannya lebih besar dari capital yang dimiliki oleh nasabah, sehingga akan menyulitkan nasabah itu sendiri dalam memenuhi kewajibannya, setiap bulan membayar angsurannya, jadi pertimbangannya harus disesuaikan, capital yang dimiliki oleh nasabah harus lebih besar dengan nilai pembiayaan yang diajukannya, jika ingin pengajuannya disetujui oleh pihak bank BNI Syariah Makassar. Jika tidak nasabah, ditawarkan untuk menurunkan jumlah nominal pembiayaan yang diajukannya. Setelah dilakukan analisis atas karakter dan capital dari nasabah UMKM yang mengajukan pembiayaan, selanjutnya dilakukan atas (capacity) kapasitas atau kemampuan nasabah pembiayaan melakukan pembayaran atau angsuran atas pembiayaannya biasanya bersifat bulanannya. Artinya dilihat berapa besar penghasilan si nasabah, jika dia pelaku UMKM berapa pendapatannya setiap bulan dari usahanya, sehingga dipastikan angsuran nasabah lebih kecil dengan pendapatannya. Karena menetukan angsuran juga ada hitungannya, hanya beberapa persen dari total pendapatan nasabah. Karena tidak mungkin semua pendapatan nasabah apalagi UMKM digunakan untuk membayar angsurannya. Nasabah harus mengeluarkan untuk keperluan pribadi dan keluarganya, kemudian juga biaya untuk operasional dari usahanya, agar usahanya tetap dapat berjalan. Jangan sampai jika nominal angsuran yang besar mengakibatkan usaha nasabah malah jadi terham bat atau tidak lancar, jadi secara teknis sudah ada hitung-hitungannya untuk menetukan sejauh mana kapasitas atau kempuan dari nasabah dapat memenuhi angusran atas pembiayaannya. Kembali lagi BNI Syariah sebagai lembaga intermediary yang ingin menyalurkan pembiayaan kepada nasabah, khususnya untuk pembiayaan produktif termasuk UMKM, jadi pembiayaan diberikan menjadi support untuk sektor riil, bukan untuk sebagai penghambat, bank BNI Syariah akan merasa senang jika nasabah yang dibiayinya usahanya makin maju dan semakin berkembang, sehingga menjadikan keberhasilan dalam menyalurkan pembiayaan. Makanya kapasitas ini juga menjadi penting dalam memberikan pembiayaan kepada nasabah, harus diukur dengan tepat kemampuan si nasabah. Jika nasabah misalnya mengajukan pembiayaan yang angsurannya besar tapi kemampuannya itu dibawah yang diajukan biasanya kita minta agar waktunya lebih diperpanjang agar nominalnya bisa lebih kecil.

Selanjutnya analisis pembiayaan lainnya yaitu tentang collateral atau jaminan yang harus dimiliki oleh nasabah yang mengajukan pembiayaan tanpa terkecuali nasabah pembiayaan untuk UMKM, ini juga harus dipenuhi, ini biasanya yang menjadi hambatan bagi nasabah, jika mengajukan pembiayaan, pelaku UMKM biasanya tidak memiliki jaminan yang dapat dijadikan agunan dalam mendapatkan pembiayaan. Banyak pelaku UMKM yang ingin mengajukan pembiayaan di Bank BNI Syariah Makassar kadang jadi batal karena jaminan nasabah tidak ada kalaupun ada biasanya tidak memenuhi dari ketentuan. Sehingga unsur jaminan ini jadi hambatan, bagi sebagian para pelaku usaha UMKM untuk dibiayai. Bank mempersyaratkan jaminan dalam pembiayaan sebagai penerapan dalam unsur kehatihatian dan menerapkan risiko pembiayaan, pada dasarnya jaminan tidak terlalu menjadi pertimbangan dalam memenuhi kebutuhan pembiayaan nasabah. 


\section{Jurnal Ilmiah Ekonomi Islam, 7(02), 2021, 630}

Selain itu yang menjadi pertimbangan bagi bank BNI Syariah dalam memberikan pembiayaan kepada nasabah yaitu unsur $1 \mathrm{~S}$, ini unsur yang juga amat penting, meskipun 5C nya terpenuhi tetapi jika yang 1S ini tidak terpenuhi otomatis pembiayaan akan dibatalkan oleh Bank syariah. Unsur 1S ini adalah syariah, yang mana semua pembiayaan nasabah yang diajukan harus memnuhi unsur syariah, tidak boleh tidak. Meskipun usaha nasabah layak untuk dibiayai secara matematis tetapi usaha itu melanggar aturan syariah maka tidak akan diberikan pembiayaan, meskipun secara ekonomis akan memberikan keuntungan baik bagi para pelaku bisnis maupun untuk bank syariah itu sendiri.

Masih terkait dalam penerapan manajemen risiko dalam memberikan pembiayaan pada pelaku usaha UMKM, ada lagi yang harus dipenuhi ketika mengajukan pembiayaan di Bank BNI Syariah Makassar. Pelaku usaha UMKM telah menjalankan usahanya minimal selama 6 bulan, jadi usaha yang benar-benar baru kemudian mengajukan pembiayaan ke Bank BNI Syariah Makassar, akan amat sangat dipertimbangkan untuk diberikan pembiayaan. Kenapa harus enam bulan, jadi pihak bank sudah memiliki gambaran tentang cash flow dari usaha UMKM tersebut, bank sudah dapat mengukur sebesar apa pendapatan dari pihak nasabah, kemudian juga jadi gambaran bagi pihak bank untuk memberikan pembiayaan, beda dengan usaha termasuk UMKM yang baru, bank akan kesulitan melihat cash flow atau keuangan yang dimiliki usaha tersebut. Jadi pertimbangannya kembali lagi ada gambaran bagi bank BNI Syariah Makassar dalam memberikan besaran atau nominal pembiayaan yang akan diberikan kepada nasabah usaha UMKM. Jadi dengan telah berjalannya usaha minimal maka bank akan melihat sejauh mana pendapatan yang diperoleh nasabah selama usahanya berdiri, kemudian potensi apa yang dimiliki usaha nasabah untuk kedepannya. Bank syariah benar-benar harus mengetahui kondisi dari usaha UMKM yang dimilikinya, jangan sampai usaha itu sebenarnya belum layak, tapi dipaksakan untuk dibiayai, sehingga akan menyulitkan pemilik usaha itu sendiri, akibatnya usaha yang mestinya masih harus dirintis malah terkendala karena harus memenuhi kewajibannya kepada bank syariah yang memberikan pembiayaan.

Usaha UMKM yang akan dibiayai oleh Bank BNI Syariah adalah UMKM yang telah menjalankan usahanya minimal 6 bulan, jenis usaha UMKM apa saja, selama layak dan tidak bertentangan dengan prinsip syariah. Waktu 6 bulan itu, biasanya bisnis nasabah sudah diketahui sejauh mana perkembangannya kemudian juga bisa dianalisi pendapatan dari usaha nasabah. Jadi menetukan angusran dan kapasitas sebagaimana sebelumnya itu dapat ditentukan, sedangkan jika usaha masih baru apanya yang mau diukur dan dianalisis. Jaminan tidak semata jadi pertimbangan dalam menentukan usaha itu layak diberi pembiayaan atau tidak, termasuk bagi usaha yang baru, jadi bukan karena nasabah punya jaminan yang mencukupi kemudian lantas diberikan pembiayaan, apalagi pengajuannya untuk tujuan penngembangan usaha, maka kualitas atau rekam jejak dari usaha, khususnya laporan keuangan yang dimiliki usaha itu akan menjadi pertimbangan. Dengan demikian usaha UMKM yang sudah berjalan minimal 6 bulan, jika membutuhkan pembiayaan untuk pengembangan usaha, atau untuk permodalan kami persilahkan untuk diajukan di bank BNI Syariah Makassar, komitmen dalam pengembangan sektor riil UMKM.

Masih terkait dengan nominal pembiayaan, jika maksimal pembiayaan UMKM itu biasanya 1 Milyar, maka untuk minimalnya 5 juta rupiah (5.000.000), jadi minal ini akan sangat membantu bagi UMKM yang mendapatkan pembiayaan untuk mengembangkan usahanya. Apalagi jika UMKM itu masih terbilang masih tahap perkembangan proses usaha rintisan adanya pembiayaan 5 juta mereka akan sangat terbantu, kemudian untuk pengajuan jaminan juga relative kecil dan mungkin hampir semua pelaku UMKM dapat memenuhi jaminan tersebut untuk memperoleh pembiayaan di Bank BNI Syariah. Meskipun minimal 5 juta rupiah, tapi banyak pelaku UMKM yang mengajukan pembiayaan diatas itu, apalagi usaha-usaha yang memang sudah cukup berkembang dan punya pelanggan, dan memiliki pendapatan yang memadai biasanya pembiayaan yang diajukannya diatas dari nominal minimal, apalagi usaha UMKM yang ingin mengembangkan usaha lain, ataupun UMKM yang ingin membuka cabang atau ingin menambahkan lokasi usahanya. Jadi pembiayaannya juga pastinya cukup besar diatas dari pembiayaan minimal. Terkait dengan nominal pembiayaan baik itu maksimal maupun nominal kita persilahkan kepada nasabah untuk mengajukan sesuai dengan kebutuhan dan kemapuannya. Jadi biasanya jika yang diajukan terlalu kecil sedangkan peruntukannya sebenarnya untuk besar, maka nasabah 


\section{Jurnal Ilmiah Ekonomi Islam, 7(02), 2021, 631}

disarankan untuk meningkatkan nominal pembiayaannya, karena jangan sampai terlalu kecil untuk memenuhi kebutuhannya khususnya jika diperuntukan pengembangan usaha, begitupun jika yang diajukan terlalu besar diluar kemampuannya, biasanya pihak bank syariah memberikan saran untuk menurunkan nilai nominal pembiayaan yang diajukan nasabah. Jadi untuk minimal pembiayaan yang dipenuhi untuk nasabah pembiayaan UMKM minimal 5 juta rupiah, berlaku di Bank BNI Syariah Makassar.

Di bank syariah tidak dikenal dengan kredit atau pinjaman yang membebankan bunga pada nasabah, melainkan menggunakan skema pembiayaan. Nah dalam perbankan syariah skema pembiayaan ini bermacam-macam ada yang bersifat jual beli, ada yang bersifat sewa, dan bersifat kerjasama atau bagi hasil, jikapun menggunakan skema pinjam, maka tidak diperbolehkan bank mengambil kelebihan termasuk untuk bunga. Karena segaimana fatwa DSN MUI terkait bunga bank yang ada di bank konvensional, maka di bank syariah harus bebas bunga, karena haram berdasarkan fatwa DSN MUI. Berbeda dengan skema pembiayaan yang tiga macam itu, dimana bank diperbolehkan mendapatkan pendapatan atau keuntungan melalui kegiatan pembiyaan. Jadi bank syariah itu lembaga bisnis yang juga berorientasi pada bisnis untuk memperoleh profit, sehingga dalam pembiayaan di bank syariah dipersilahkan atau boleh untuk memperoleh keuntungan. Baik bank konvensional maupun bank syariah sama-sama lembaga bisnis, yang mencari keuntungan, yang membedakan adalah proses untuk memperoleh keuntungan itu, yang satu boleh yang satunya tidak boleh. Sehingga pelarangannya bukan pada tujuannya tapi proses mencapai tujuannya itu. Jadi sama-sama punya tujuan untuk mendapatkan profit tapi yang membedakan proses memperoleh keuntungan.

Kembali lagi pada akad yang digunakan bank syariah dalam menyalurkan pembiayaan di Bank BNI Syariah Makassar untuk nasabah pembiayaan yang peruntuhkan bagi pelaku UMKM, jadi akad yang digunakan disesuaikan dengan kebutuhan dari nasabah, jika diperuntuhkan untuk pengadaan barang, maka diberikan untuk menggunakan jenis akad pembiayaan jual beli dengan model murabahah. Kemudian jika untuk modal kerja, khususnya bentuk pembiayaan untuk modal usaha biasanya menggunakan akad kerjasama atau bagi hasil dengan model musyarakah. Jadi perlu saya sampaikan bahwa skema pembiayaan di bank syariah ada jual beli, sewa menyewa, dan bagi hasil atau kerjasama. Dalam aplikasinya juga berbeda, antara masing-masing akad ini. Pada pembiayaan jual beli modelnya terdiri dari murabahah, salam, dan istisnha', untuk pembiayaan sewa menggunakan akad ijarah dan ijarah muntahiyyah bittamlik, kemudian untuk skema bagi hasil terdiri dari mudharabah dan musyarakah. Jadi akad jual beli murabahah adalah akad jual beli dimana pihak penjual menyebutkan nominal berapa harga barang serta besaran yang dinginkan dari pihak bank. Kemudian jual beli salam adalah jual beli dalam bentuk pesanan, yang mana proses penyerahannya dilain waktu, namun pembayarannya dilakukan diawal. Dan akad jual beli istisnha' sama jual beli salam yaitu jual beli dalam bentuk pesanan, yang membedakan pada proses pembayarannya yang mana pembayarannya dapat dilakukan diakhir atau melalui angsuran atau pertengahan. Adapun pembiayaan skema sewa menyewa atau biasa disebut dengan akad Ijarah, yaitu sewa tanpa ada perpindahan kepemilikan dari objek yang disewa, jadi disewa sesuai waktu yang disepakati kemudian hak milik barang tetap si pemilik barang. Kemudian ada akad sewa bentuk Ijarah Muntahiyyah Bittamlik (IMBT) hampir sama dengan akad ijarah sebelumnya, hanya saja diakhir masa sewa, objek atau barang yang disewa menjadi milik si penyewa, jadi ada perpindahan kepemilikan. Adapun pembiayaan dengan skema bagi hasil khususnya di bank syariah yang biasa digunakan ada dua model yaitu akad mudharabah dan akad musyarakah. Penggunaan akad dalam memberikan pembiayaan nasabah pelaku UMKM di bank BNI Syariah Makassar disesuaikan dengan kebutuhan dan keperluan dari nasabah. Jika dipelaku usaha UMKM mengajukan pembiayaan untuk keperluan pengadaan barang, maka bank syariah dapat memberikan skema jual beli murabahah. Dimana pihak bank akan membelikan barang yang dibutuhkan nasabah kemudian mejualnya kepada pelaku usaha UMKM yang mengajukan pembiayaan. Misalnya ada pelaku UMKM yang memiliki keperluan untuk pemenuhan barang yang dapat menunjang usahanya, dan diperlukan segera biasa diberikan pembiayaan UMKM menggunakan murabahah. Pihak bank bertindak sebagai penjual memenuhi kebutuhan barang yang diinginkan nasabah, kemudian menjual barang tersebut kepada nasabah. Kemudian akad musyarakah diberikan bagi pembiayaan untuk UMKM, untuk keperluan penambahan modal usaha, 
jadi biasa diperuntuhkan untuk pengembangan usaha, misalnya penambahan tempat bisnis, atau untuk penambahan volume keperluan bisnis yang sifatnya tentative, atau belum saat itu juga. Jadi pihak Bank syariah dengan nasabah sama-sama menyertakan modal untuk pengembangan usaha, kemudian hasilnya dibagi sesuai dengan kesepakatan dari keduanya. Dalam perlakuan pengawasan terhadap nasabah pembiayaan maka nasabah pembiayaan dengan skema musyarakah akan mendapat pengawasan yang lebih dan pendampingan maksimal dari pihak bank syariah. Mengingat skema musyarakah pihak bank syariah akan memperoleh keuntungan yang tidak pasti. Sehingga pengawasan kepada nasabah pembiayaan musyarakah lebih intens jika disbanding dengan nasabah pembiayaan untuk murabahah. Pembiayaan dengan akad jual beli murabahah pihak bank akan memperoleh keuntugan yang bersifat pasti sedangkan pembiayaan yang menggunakan akad kerjasama musyarakah bank tidak mendapat kepastian dalam keuntungan. Jika usaha yang dibiayai memperoleh keuntungan maka pihak bank dapat memperoleh keuntungan, namun jika usaha yang dibiayai tidak mendapatkan keuntungan atau bahkan mengalami kerugian maka pihak bank syariah siap menanggung risiko kerugian tersebut. Jadi penggunaan akad baik jual beli musyarakat maupun akan pembiayaan musyarakah untuk pembiayaan UMKM disesuaikan dengan kebutuhan dari nasabah pelaku UMKM.

Kemudian ada yang menanyakan, untuk pembiayaan untuk usaha mikro di Bank BNI Syariah Makassar, apakah menggunakan jaminan atau agunan untuk memperoleh pembiayaan untuk UMKM. Sebagaimana dijelaskan sebelumnya bahwa dalam penyaluran pembiayaan di bank syariah baik untuk usaha mikro maupun untuk lainnya bank syariah menerapkan prinsip $5 \mathrm{C}+1 \mathrm{~S}$, didalamnya ada collateral atau jaminan, maka harus dipenuhi, oleh calon nasabah pembiayaan, hal ini dalam merangka menjaga agar pembiayaan dapat berjalan dengan lancar, dan dapat diatasi jika terjadi kendala dalam proses pembiayaan nasabah. Untuk jenis jaminan atau agunan disesuaikan dengan nominal pembiayaan yang diajukan di bank syariah. Biasanya jika pembiayaannya kecil nasabah banyak menggunakan jaminan BPKB kendaraan baik motor maupun mobil. Kemudian yang pembiayaan yang besar biasanya menggunakan jaminan sertifikat tanah atau sertifikat bangunan. Jadi jaminan yang menjadi agunan nasabah dinilai dulu harganya, kemudian ditaksir ditawarkan besaran nominal pembiayaan diajukan, jika ternyata yang diajukan terlalu besar disbanding nilai jaminannya maka disarankan ke nasabah untuk menurunkan nominal pembiayaannya. Tetapi jika ternyata nilai jaminan lebih besar dari nominal pembiayaan yang diajukan maka, sangat memudahkan nasabah untuk memperoleh pembiayaan, dengan ketentuan syarat lain terpenuhi. Untuk jaminan yang berupa sertifikat, baik tanah, rumah, atau bangunan lainnya, dipastikan bahwa dalam sertifikat tersebut sudah atas nama nasabah yang mengajukan pembiayaan, tidak boleh miliki keluarga, orang tua atau orang lain. Jadi sertifikat sudah atas nama nasabah pembiayaan. Jadi semua pembiayaan di bank BNI Syariah Makassar mempersyaratkan jaminan, tidak ada pembiayaan tanpa jaminan.

Selanjutnya tentang jangka waktu atau masa lama pembiayaan di Bank BNI Syariah Makassar untuk pembiayaan UMKM. Yang berlaku saat ini jangka waktu pembiayaan itu 6 bulan paling cepat dan paling lama itu 7 tahun. Dalam masa pembiayaan nasabah boleh saja melakukan pembayaran pelunasan lebih cepat, khususnya bagi nasabah yang dianggap mampu dan mungkin saat itu telah memiliki dana. Kemudian nasabah kita persilahkan untuk melakukan pembiayaan kembali jika mau, nasabah yang memiliki record yang baik akan lebih mudah untuk memperoleh kembali pembiayaan dari Bank BNI Syariah Makassar. Karena biasanya ada nasabah yang telah melakukan pembiayaan, namun ditengah proses pembiayaan dia membutuhkan pembiayaan yang lebih besar, biasanya nasabah melunasi dahulu pembiayaan yang sebelumnya lalu kemudian mengajukan kembali pembiayaan dengan nominal lebih besar dari sebelumnya. Jika dianggap layak sama pihak bank maka dipersilahkan untuk mengajukan pembiayaan. Kemudian bagi nasabah yang bermasalah atau habis jangka waktu pembayaran belum juga maka dilakukan restrukturisasi pembiayaan, dengan memperpanjang jangka waktu pembayaran. Jadi waktu masa pembiayaan di bank syariah untuk pelaku usaha UMKM, itu cukup panjang dipersilahkan bagi nasabah untuk menetukan waktunya sesuai dengan keingan dengan kebutuhan nasabah saja. Nasabah yang pembiayaanya sudah jatuh tempo atau selesai, maka dipersilahkan untuk mengajukan kembali pembiayaan baru, baik dengan nominal yang sama atau dengan nominal yang lebih besar. Nanti akan jadi pertimbangan bagi pihak bank dalam menentukan 
layak atau tidak untuk diberi pembiayaan kembali. Termasuk jika nasabah pembiayaan memiliki record kurang baik pada saat pembiayaan, biasanya pihak bank tidak kembali menawarkan pembiayaan bagi nasabah. Jadi dalam masalah waktu pembiayaan untuk nasabah pembiayaan termasuk UMKM, bisa sampai jangka waktu yang telah disepakati atau bisa melakukan pelunasan lebih cepat dari waktu yang diajukan.

Dari uraian diatas maka pihak bank BNI Syariah sudah dipastikan memberikan atau menyalurkan pembiayaan bagi nasabah UMKM. Terbukti bahwa bank BNI Syariah memberikan porsi khusus sebesar $20 \%$ bagi nasabah pembiayaan pelaku UMKM, kemudian BNI Syariah Makassar memberikan layanan yang khusus untuk UMKM dengan menghadirkan kantor layanan BNI Syariah Mikro di Makassar dan beberapa daerah di Sulawesi Selatan. Dalam menyalurkan pembiayaan kepada nasabah UMKM, tetap memiliki ketentuan dan syarat yang harus dipenuhi oleh para nasabah pembiayaan yang berlaku, agar dapat memperoleh pembiayaan. Kemudian nominal pembiayaan yang dapat diajukan oleh para pelaku UMKM untuk pembiayaan di Bank BNI Syariah Makassar sebesar minimal 5 juta rupiah, dan maksimal 1 milyar rupiah. Nominal ini mungkin bisa ditambah lagi maksimalnya, mengingat saat ini pelaku UMKM juga memiliki asset yang cukup besar, apalagi pelaku usaha yang ingin mengembangkan usahanya, yang ingin meningkatkan produksinya, atau menambah produksinya. Kemudian nominal juga mungkin dapat ditunkan dikisaran 2 juta rupiah, hal ini perlu untuk meningkatkan animo masyarakat untuk menggunakan perbankan syariah. Nasabah yang dibiayai oleh bank BNI Syariah harus memiliki jaminan/ agunan, walaupun pembiayaannya terbilang kecil.

Selanjutnya untuk UMKM yang ingin mengajukan pembiayaan di Bank BNI Syariah telah berjalan usahanya minimal 6 bulan. Hal ini mungkin harus jadi pertimbangan, sebaiknya bank syariah harus ikut membersamai usaha yang dilakukan UMKM, akan lebih baik jika dari awal Bank BNI Syariah Makassar memberikan pembiayaan termasuk untuk usaha-usaha yang masih terbilang baru, tanpa harus menunggu telah berjalan 6 bulan atau lebih. Hal ini akan menghilangkan stigma bahwa usaha yang ingin dibiayai oleh bank syariah hanya usaha yang sudah maju, bukan usaha yang dari awal. Dalam menyalurkan pembiayaan untuk pelaku usaha UMKM
Bank BNI Syariah Makassar menggunakan akad murabahah dan musyarakah. Dalam kondisi untuk kegiatan bisnis khususnya UMKM, maka akad yang lebih pas adalah akan dengan skema bagi hasil baik itu musyarakah maupun mudharabah. Mengingat pelaku usaha pendapatannya bersifat tidak pasti, dalam usaha bisa saja memperoleh keuntungan besar, atau keuntungan yang kecil. Kecuali untuk pembiayaan yang bersifat konsumtif sebaiknya menggunakan akad murabahah yang pasti pendapatannya. Waktu pembiayaan yang berlaku bagi nasabah pembiayaan untuk UMKM minimal 6 bulan dan paling lama 7 tahun. Untuk minimal mungkin tidak perlu ada minimal, meskipun baru sebulan jika nasabah mampu melunasi, sebaiknya diberi kemudahan, begitun jika pembiayaan 7 tahun, jika pelunasan lebih cepat maka dapat diberi kemudahan, sehingga nasabah dapat dengan mudah mengembalikan pembiayaannya. Bank BNI Syariah sebagai lembaga intermediary telah menyalurkan pembiayaan kepada para pelaku usaha UMKM. Bank BNI Syariah Makassar ikut dalam pengembangan sektor riil UMKM, khususnya dalam penyaluran pembiayaan, dan memberikan akses kepada para pelaku usaha UMKM untuk meningkatkan usaha yang dimilikinya.

\subsection{Penyaluran Pembiayaan untuk UMKM di PT. Bank Panin Dubai Syariah Cabang Makassar}

Bank Panin Dubai Syariah, yang sebelumnya bernama bank Panin Syariah, merupakan anak usaha dari PT. Bank Panin Konvensional, yang berkomitmen dalam memberikan layanan yang maksimal di bidang layanan perbankan syariah. Bank Panin Dubai Syariah merupakan salah satu perbankan yang awal keberadaannya cepat meningkatkan statusnya dari Unit Usaha Syariah (UUS) menjadi Bank Umum Syariah (BUS). Setelah menjadi BUS, Bank Panin Dubai Syariah semakin besar dan semakin luas dalam meningkatkan layanan, bahkan kantor cabang bank Panin Dubai Syariah semakin banyak ditemui diberbagai daerah di kota Indonesia. Bahkan Bank Panin Dubai Syariah mencapai prestasi sebagai bank syariah yang pertama kali melantai di bursa atau membuka diri untuk Initial Publik Offering (IPO). IPO menjadikan Bank Panin Dubai Syariah sebagai bank syariah yang sahamnya dapat di beli di pasar modal. Pada kegiatan atau transaksinya seperti bank syariah lain, Bank Panin Dubai Syariah hampir sama dengan bank syariah lainnya menyediakan produk penghimpunan dana (funding), dan produk penyaluran 


\section{Jurnal Ilmiah Ekonomi Islam, 7(02), 2021, 634}

dana (financing), dan jasa perbankan lainya. Tetap sama bank Panin Dubai Syariah sebagai lembaga intermediary yang menyalurkan pembiayaan kepada masyarakat dari dana yang dihimpunannya.

Walaupun Bank Panin Dubai Syariah terbilang bank syariah baru, ternyata bank Panin Dubai Syariah juga menyalurkan pembiayaan pada sektor usaha mikro UMKM. Bank Panin Dubai Syariah ingin berkontribusi dalam pengembangan sektor riil UMKM, melalui penyaluran pembiayaan untuk UMKM. Bank Panin Dubai Syariah ikut berkontribusi dalam pembiayaan sektor riil UMKM. Hal ini diwujudkan dengan penyaluran pembiayaan untuk UMKM yang dilakukan oleh Bank Panin Dubai Syariah Kantor Cabang Makassar Sulwesi Selatan. Berikut hasil wawan cara dengan Bapak Bambang selaku pihak yang bergerak pada divisi pembiayaan UMKM di Bank Panin Dubai Syariah Makassar.

Bank Panin Dubai Syariah masih terbilang bank syariah baru di kota Makassar, namun dalam penyaluran pembiayaannya memberikan porsi $20 \%$ untuk disalurkan untuk UMKM, hal ini tidak lepas dari potensi dan lingkungan yang ada di kota Makassar ini, saat ini makin bermunculan pengusahapengusaha baru, termasuk pelaku usaha pada UMKM. Dapat kita lihat banyaknya usaha-saha baru yang hadir, itu artinya kota Makassar memiliki potensi yang besar dalam pengembangan usaha, khususnya pada sektor UMKM. Jadi setiap usaha yang baru lahir pasti membutuhkan dana dalam proses kedepannya dan dalam memenuhi kebutuhan usaha. Maka peluang yang coba dibaca dan ditangkap oleh pihak Bank Panin Dubai Syariah Makassar, untuk dapat mengembangkan usahanya. Ada potensi yang besar untuk memberikan pembiayaan bagi pelaku usaha UMKM. Makin banyak bermunculan pengusaha itu menjadi peluang untuk membuka segmen baru dalam pembiayaan, jadi selain membiayai usaha yang sudah besar bank syariah juga memberikan porsi untuk pembiayaan pada segmen mikro (UMKM).

Untuk besaran pembiayaan yang ditawarkan Bank Panin Dubai Syariah Makassar untuk pembiayaan UMKM mencapai dengan nominal 500 juta sampai dengan 2 milyar rupiah, jadi UMKM yang benarObenar membutuhkan modal dalam pengembangan usaha, bank Panin Dubai Syariah Makassar selalu siap mendukung, dan menyediakan pembiayaan. Pengajuan pembiayaan pastunya harus mengikuti peraturan dan ketentuan yang berlaku di Bank Panin Dubai Syariah. Ada beberapa ketentuan dan syarat yang harus dipenuhi oleh pihak nasabah untuk dapat memperoleh pembiayaan, hal itu hampir sama dengan bank-bank syariah lainnya. Untuk masa pembiayaan yang ditentukan Bank Panin Dubai Syariah Makassar menetapkan untuk lama waktu pembiayaan yaitu masa waktu 1 sampai 5 tahun, ini sejalan dengan keperluan dan kebutuhan nasabah. Selain itu ketentuan lain yaitu jaminan juga menjadi keharusan bagi pelaku UMKM yang ingin memperoleh pembiayaan dari Bank Panin Dubai Syariah, yang kedepannya dapat menjadi pertimbangan bagi bank syariah memberikan pembiayaan. Nominal besaran pembiayaan juga mengikuti dari nilai agunan atau jaminan yang diajukan oleh pihak nasabah. Agar memudahkan bank syariah dalam memberikan pembiayaan untuk nasabah UMKM sebaiknya jaminan dapat terpenuhi dan nilainya lebih besar disbanding dengan nominal pembiayaannya. Jadi pada prinsipnya sama dengan bank syariah lainnya, setiap nasabah yang mengajukan pembiayaan termasuk nasabah untuk usaha UMKM, akan dilakukan analisis pembiayaan dengan prinsip $5 \mathrm{C}+1 \mathrm{~S}$, dimanapun ini harus diterapkan tanpa terkecuali pembiayaan di Bank Panin Dubai Syariah. Termasuk untuk pembiayaan yang bukan UMKM juga berlaku analisis tersebut.

Jika dilihat dan dibandingkan dengan bank syariah lainnya, porsi pembiayaan mikro (UMKM) yang dimiliki oleh Bank Panin Dubai Syariah lebih besar sehingga segmen mikro yang lebih tinggi atau menengah juga dapat dijangkau. Sebagai bank syariah yang belum lama ada di kota Makassar untuk pembiayaan UMKM, memang belum maksimal, apalagi belum adanya komunitas atau perkumpulan yang menjadi binaan dari Bank Panin Dubai Syariah. Mungkin berbeda dengan dengan bank syariah yang sudah hadir terlebih dahulu, atau lembaga keuangan yang memang menfokuskan diri pada segmen UMKM, yang mungkin telah memiliki binaan usaha, untuk Bank Panin Dubai Syariah Makassar sendiri belum memiliki, tapi perlahan akan diarahkan juga dicarikan jalan agar bisa berkembang lebih baik lagi kedepannya. Dengan pemberian pembiayaan dikisaran nominal 500 juta sampai dengan 2 milyar, maka segmen yang menjadi prioritas untuk pembiayaan UMKM, jadi lebih cocok untuk usaha yang sifatnya kecil dan menengah, kalau untuk usaha mikro harus lebih kecil nominalnya. Kan kalau usaha kecil biasanya keberadaannya sudah cukup lama bukan yang benar-benar baru, sehingga dapat 
dipelajari perkembangan usahanya. Usaha pada level kecil diatas dari usaha mikro yang memang sangat terbatas, dan akses keuangan juga terbatas, apalagi jika usahanya masih sangat baru berat bagi lembaga keuangan untuk menyalurkannya. Jadi usaha kategori kecil dan menengah dengan nomimal pembiayaan yang bisa dibilang cukup besar dari Bank Panin Dubai Syariah akan mudah diakses dan diterima. Tapi tetap diupayakan untuk bisa membiayai yang segmen mikro jika kondisi memungkin, sehingga pembiayaan UMKM dapat ditawarkan secara keseluruhan. Pada intinya penawaran pembiayaan UMKM dengan nominal tersebut diats dianggap lebih pas jika untuk memenuhi pembiayaan dengan jenis usaha kecil dan menengah. Jenis-jenis usaha yang membutuhkan modal dalam mengembangkan usahanya, misalnya ingin membuka cabang baru, menambah produksi usaha, dan lainnya yang akan dipenuhi dalam pembiayaan untuk UMKM di Bank Panin Dubai Syariah Makassar.

Selanjutnya terkait dengan apa yang digunakan, bagi nasabah pembiayaan pelaku usaha UMKM yang digunakan di Bank Panin Dubai Syariah, kebanyakan menggunakan akad murabahah atau jual beli, kemudian juga menggunakan akad musyarakah untuk pemenuhan modal kerja. Jadi hampir sama dengan model pembiayaan di bank syariah lainnya, jika tujuannya untuk pengadaan barang, maka akan diberikan akad murabahah, jika untuk penambahan modal maka akan diberi akad musyarakah. Misalnya ada nasabah punya usaha masuk dalam kategori UMKM, ingin menambah armada kendaraannya untuk mendukung kegiatan usahanya, maka akad yang digunakan jika nasabah melakukan pembiayaan yaitu akad murabahah. Jadi pihak Bank Panin Dubai Syariah akan memenuhi keperluan nasabah tersebut, pihak bank akan membeli barang tersebut terlebih dahulu, kemudian menjualnya kepada nasabah yang memiliki usaha. Dengan kesepatakan harga diawal, dan jangka waktu pembayaran.

Bank Panin Dubai Makassar memberikan porsi $20 \%$ dari total pembiayaan yang disalurkan untuk keperluan pembiayaan UMKM. Bisa dibilang masih kecil porsinya, sehingga perlu ditingkatkan dan ditambah volumenya, mengingat segmen yang banyak berkembang dan membutuhkan bantuan permodalan yaitu segmen usaha UMKM. Besaran pembiayaan yang dapat diajuakan nasabah pembiayaan UMKM dari 500 juta rupiah sampai dengan 2 milyar rupiah, nominal sebesar ini akan dianggap besar bagi pelaku
UMKM, yang biasanya kebutuhanya tidak begitu banyak, apalagi UMKM yang baru dalam proses rintisan, atau baru mau berkembang dengan nominal pembiayaan sebsar itu akan berat. Sebaiknya nominalnya diturunkan sehingga produknya dapat dijangkau oleh seluruh pelaku usaha UMKM. Dalam penjelasannya disampaikan bahwa memang angka sebesar itu lebih diprioritaskan untuk usaha UMKM yang berjenis kecil dan menengah, untuk yang mikro belum jadi prioritas utama. Karena memang dengan nominal tersebut cocok bagi usaha kecil dan menengah yang membutuhkan batuan modal untuk fokus pengembangan usaha, bukan usaha yang baru dirintis. Untuk pengajuan pembiayaan untuk usaha UMKM maka tetap dipersyaratkan untuk menyediakan jaminan atau agunan yang dapat memenuhi besaran pembiayaan yang diajukan. Kemudian untuk jangka waktu pembiayaan untuk UMKM di Bank Panin Dubai Syariah Makassar antara 1 sampai dengan 5 tahun. Hal ini terlalu pendek jika dilihat dari nominal pembiyaan yang cukup besar, sebaiknya waktu dapat diperpanjang apalagi nominal pembiayaanya cukup besar.

Pembiayaan untuk usaha UMKM di Bank Panin Dubai Syariah Makassar, menyalurkan pembiayaan pada sektor produktf, sehingga akan memberi kontrobusi bagi sektor riil kedepannya. Hanya saja karena Bank Panin Dubai Syariah masih terbilang baru dalam penyaluran baru maka masih sangat terbatas dalam menyalurkan pembiayaan untuk pengembangan UMKM, ini juga terlihat dari penyaluran pembiayaannya yang masih didominasi untuk keperluan konsumtif. Untuk kedepannya bank Panin Dubai Syariah Makassar perlu meningkatkan pembiayaan produktifnya khususnya untuk pelaku UMKM, dan memberikan kemudahan akses untuk memperoleh pembiayaan. Dukungan dari semua pihak dibutuhkan untuk meningkatkan peran pihak bank syariah dalam berkontribusi dalam pengemabngan ekonomi di negara ini, salah satunya melalui peningkatan volume dari pelaku ushaa UMKM.

4.4. Integrasi Peran Pembiayaan Perbankan Syariah Terhadap Sektor UMKM Dengan Pengembangan Program Studi Perbankan Syariah

Dalam penyusunan kurikulum program studi perbankan syariah mengitegrasikan dengan pembelajaran yang terkait dengan pembiayaan di bank syariah termasuk untuk pembiayaan untuk UMKM. Dalam merespon hal itu program perbankan syariah 


\section{Jurnal Ilmiah Ekonomi Islam, 7(02), 2021, 636}

memberikan mata kuliah khusus yang membahas tentang pembiayaan di bank syariah, kemudian juga mata kuliah yang membahas tentang UMKM yang harus ditempuh para mahasiswa. Mata kuliah manajemen pembiayaan bank syariah di tempuh pada semester 6 dan untuk mata kuliah UMKM ditempuh pada semester 3. Sehingga mahasiswa akan lebih mengenal dan mempelajari pola pembiayaan dan berbagai jenis usaha yang dibiayai oleh perbankan syariah. Dalam mata kuliah Koperasi dan UMKM, maka disajikan jenis-jenis UMKM yang ada, kemudian bagaimana kegiatan UMKM dapat berkontribusi dalam perputaran ekonomi yang ada saat ini. Kemudian jenis-jenis UMK dengan berbagai kriteria sehingga dapat dikelompok UMKM kategori mikro, usaha kecil, dan usaha menengah, serta kendala-kendala. Untuk mata kuliah manajemen pembiayaan perbankan syariah menguraikan tentang tujuan dari pembiayaan di bank syariah. Kemudian tujuan dan peruntukan pembiayaan yaitu untuk kegiatan konsumtif dan produktif. Tujuan produktif terdiri dari dua yaitu dalam bentuk investasi dan modal kerja. Serta pendalaman tentang akad-akad yang dapat digunakan perbankan syariah dalam menyalurkan pembiayaan. Peluang bagi bank syariah dalam pengembangan penyaluran pembiaayaan yang disalurkan untuk pelaku usaha sektor riil UMKM. Kemudian penerapan akad-akad tersebut dalam pembiayaan.

\section{KESIMPULAN}

a. Perkembangan pembiayaan bank syariah pada sektor UMKM, mengalami pertumbuhan pada jenis Bank Umum Syariah (BUS) pertumbuhan pembiayaan untuk sektor mikro (UMKM) pada periode tahun 2019 sampai dengan maret 2020 tumbuh sebesar mencapai 15,93 persen, untuk bank syariah jenis Bank Pembiayaan Syariah (BPRS) tumbuh sebesar 4,57 persen, sedangkan bank syariah jenis Unit Usaha Syariah (UUS) untuk penyaluran pembiayaan untuk UMKM mengalami penurunan sebesar $-2,7$ persen.

b. Peran pembiayaan perbankan syariah terhadap sektor UMKM di Kota Makassar, khususnya untuk Bank BNI Syariah Makassar menyalurkan pembiayaan untuk UMKM khususnya dengan memberikan porsi 20 persen dari total pembiayaan yang disalurkan. Bank Panin Dubai Syariah juga menyalurkan pembiayaan pada UMKM, yang difokuskan untuk usaha kecil dan menengah dengan nominal pembiayaan mencapai 500 juta sampai dengan 2 milyar. Pembiayaan yang disalurkan Bank BNI Syariah Makassar dan Bank Panin Dubai Syariah Makassar untuk UMKM sangat membantu perkembangan sektor riil.

c. Integrasi peran pembiayaan perbankan syariah untuk sektor UMKM dengan pengembangan program studi perbankan syariah Universitas Islam Negeri Alauddin Makassar. Dalam perkembangannya bank syariah akan meningkatkan pembiayaan untuk sektor UMKM, dan produk lainnya. Dengan itu program studi perbankan syariah melakukan pendalaman dan pengkajian untuk kedua sektor tersebut yaitu dengan menuangkan dalam mata kuliah Manajemen Pembiayaan Bank Syariah dan Mata Kuliah Koperasi dan UMKM.

\section{REFERENSI}

Algaoud, Latifa M. dan Mervyn K. (2001). Perbankan Syariah, Prinsip, Praktik, Prospek. Jakarta: PT. Serambi Ilmu Semesta.

Asemokha, A., Musona, J., Torkkeli, L., \& Saarenketo, S. (2019). Business model innovation and entrepreneurial orientation relationships in SMEs: Implications for international performance. Journal of International Entrepreneurship. https://doi.org/10.1007/s10843-019-00254-3

Danupranata, Gita. (2006). Ekonomi Islam. Yogyakarta: UPFE-UMY.

Kara, Muslimin. (2013). Kontribusi Pembiayaan Perbankan Syariah Terhadap Pengembangan Usaha Mikro, Kecil, dan Menengah. Jurnal AsySyir'ah Jurnal Ilmu Syariah dan Hukum Vol. 47. No 1. Yogyakarta: Fakultas Syariah dan Hukum Universitas Islam Negeri Sunan Kalijaga.

Kholis, Nur. (2008). Modul Mata Kuliah Manajemen Perbankan Syariah. Yogyakarta: Prodi Ekonomi Islam Fakultas Agama Islam Universitas Islam Indonesia.

Maryati, Sri. (2014). Peran Bank Pembiayaan Syariah Dalam Pengembangan UMKM dan Agrisbisnis Pedesaan di Sumatra Barat. Jurnal Economica. Vol.3.No.1 Padang: Prodi Pendidikan Ekonomi STKIP PGRI Padang.

Muhamad. (2014). Manajemen Keuangan Syariah Analisis Fiqih dan Keuangan. Yogyakarta: UPP STIM YKPN. 
Mujaddid, Fajar dan Ghaida Fathihatu Sabila. (2018). Pengaruh Pembiayaan UMKM dan Rasio Keuangan Terhadap Pertumbuhan Laba Bank Umum Syariah di Indonesia. Jakarta: Jurnal Ekonomi Islam. Volume 9 Nomor 2, Fakultas Agama Islam Universitas Prof Hamka.

Mursal. (2016). Pengembangan Lembaga Keuangan Mikro Syariah di Sumatera Barat Berbasis Kearifan Lokal "Tungku Tigo Sajarangan". Jurnal Analitical Islamica. Volume. 5. Nomor 1. UIN Sumatera Utara Medan.

Nur, Binti Aisyah. (2014). Manajemen Pembiayaan Bank Syariah. Yogyakarta: Teras.

Otoritas Jasa Keuangan. (2019). Statistik Perbankan Syariah Oktober 2019.

Otoritas Jasa Keuangan. (2020). Statistik Perbankan Syariah Maret 2020.

Remy, Sutan Sjahdaeni. (2014). Perbankan Syariah Produk-produk dan Aspek-aspek Hukumnya. Jakarta: Kencana.

Ye, J., \& Kulathunga, K. M. M. C. B. (2019). How does financial literacy promote sustainability in SMEs? A developing country perspective. Sustainability (Switzerland). https://doi.org/10.3390/su11102990
Zamroni. (2013). Peran Bank Syariah Dalam Penyaluran Dana Bagi Usaha Mikro Kecil dan Menengah (UMKM). Kudus: Jurnal Iqtishadia, Vol. 6, No. 2, IAIN Kudus.

http://www.bankmuamalat.co.id/berita/detail/banksyariah-lebih-melirik-umkm\#.VscVSE-FrIV diakses pada tanggal 19 Februari 2016.

http://www.syariahmandiri.co.id/2013/04/bsm-patokporsi-pembiayaan-umkm-jadi-75/, Diakses pada tanggal 19 Februari 2016.

https://www.kompasiana.com/fatimahimaniarkarnina 15ac6662fdd0fa84fba50e1c4/peran-perbankansyariah-dalam-menggerakkan-usaha-mikrokecil-danmenengah\#: : :text=Dengan\%20adanya\%20pro duk\%20pembiayaan\%20bagi,UMKM\%20untuk $\% 20$ bekerja\%20secara\%20optimal.\&text=Siste $m \% 20$ perbankan\%20syariah\%20ini\%20sangat, dalam\%20menggerakkan\%20pembangunan $\% 20$ ekonomi\%20nasional. Diakses Pada tanggal 30 Maret 2020. 